\title{
IMPLEMENTASI KURIKULUM 2013 DI SMK KOTA SEMARANG
}

\author{
Wisudani Rahmaningtyas ${ }^{1)}$, Ismiyati' ${ }^{2}$, Ayunda Dwi Septianingrum ${ }^{3}$, Nurul Izza $^{4)}$ \\ Pendidikan Ekonomi, Fakultas Ekonomi, Universitas Negeri Semarang \\ Wisudani.rahmaningtyas@mail.unnes.ac.id ${ }^{13}$ Ismiyati@mail.unnes.ac.id ${ }^{22}$ Ayunda@gmail.com ${ }^{32}$ \\ Izzanurul@gmail.com ${ }^{4)}$
}

\begin{abstract}
Abstact
The result of the observation showed that the teachers have prepared lesson plans according to the Curriculum 2013 guidelines, however the lesson plans has not been quite implemented in the learning process, in addition to the lack of the availability of the infrastructures to support the learning process. The objective of the study was to determine the extent to which the implementation of the Curriculum 2013 learning and the obstacles encountered in the Archival subject by the teacher and students of $10^{\text {th }}$ Office Administration at SMK Negeri 9 Semarang. It was a qualitative research using the CIPP model of evaluation method. The results of the study showed that: 1) the mechanism of the lesson plans implementation in archive learning has been in accordance with Curriculum 2013 guidelines and the phases were complete. However, there were some inappropriateness, such as the undelivered information about the scope of the subject matter and the assessment technique, the lack of student involvement, and the absence of archive laboratory to support the learning process, 2) the obstacles in the implementation of the lesson plans in archive learning were from three sources, i.e. the teacher, the students, and the infrastructure.
\end{abstract}

Keywords: Curriculum 2013, learning process, saintific approach, active learning

\begin{abstract}
Abstrak
Hasil observasi didapatkan bahwa guru telah membuat rencana pembelajaran berupa RPP sesuai dengan pedoman Kurikulum 2013 sebagai pedoman pembelajaran, namun dalam pelaksanaannya RPP belum sepenuhnya diterapkan, serta kurangnya ketersediaan sarana prasarana pendukung pelaksanaan pembelajaran. Penelitian ini bertujuan untuk mengetahui sejauh mana pelaksanaan pembelajaran Kurikulum 2013 dan hambatan yang ditemui pada mata diklat Kearsipan oleh guru dan peserta didik kelas X jurusan Administrasi Perkantoran di SMK Negeri 9 Semarang dan SMK Palebon. Penelitian ini merupakan penelitian kualitatif, menggunakan metode evaluasi dengan model CIPP. Teknik pengumpulan data yang digunakan adalah wawancara, observasi, dan dokumentasi. Analisis data meliputi empat tahapan, yaitu: pengumpulan data, reduksi data, penyajian data, dan penarikan kesimpulan. Hasil penelitian menunjukkan bahwa: 1) mekanisme pelaksanaan pembelajaran kearsipan berupa penyusunan RPP telah sesuai dengan pedoman RPP Kurikulum 2013; pelaksanaan pembelajaran terdiri dari kegiatan pendahuluan, inti dan penutup masih terdapat poin yang belum sesuai, diantaranya belum disampaikannya lingkup dan teknik penilaian, kurangnya keterlibatan peserta didik dalam pelaksanaan pembelajaran dan belum tersedianya laboratorium khusus kearsipan, 2) hambatan dalam pelaksanaan pembelajaran kearsipan berasal dari 3 (tiga) sumber yaitu guru, peserta didik, dan sarana prasarana.
\end{abstract}

Kata kunci : Kurikulum 2013, proses pembelajaran, saintific approach, active learning 


\section{PENDAHULUAN}

Sariono (2013:2) mengemukakan bahwa, "Kurikulum merupakan landasan yang digunakan pendidik untuk membimbing peserta didiknya ke arah tujuan pendidikan melalui akumulasi sejumlah pengetahuan, keterampilan, dan sikap mental". Kurikulum dalam arti sempit diartikan sebagai kumpulan berbagai mata pelajaran atau mata kuliah yang diberikan kepada peserta didik melalui kegiatan yang dinamakan proses pembelajaran (Kwartolo, 2002). Kurikulum juga merupakan suatu perangkat mata pelajaran dan program pendidikan yang diberikan oleh suatu lembaga pendidikan atau institusi dalam bentuk rancangan pembelajaran dalam kurun waktu tertentu dan pada berbagai jenjang pendidikan. Perbaikan kurikulum dalam pendidikan dirancang mengikuti perkembangan zaman (Bariyah, 2014). Perubahan kurikulum dari waktu ke waktu berpengaruh pada perbaikan kualitas pendidikan Indonesia dari berbagai jenjang. Perubahan kurikulum antara lain bertujuan untuk menyesuaikan kurikulum pendidikan dengan perkembangan masyarakat, ilmu pengetahuan dan teknologi (Ahmad, 2014). Berbagai strategi dilakukan pemerintah khususnya Kemendikbud dan Kemenristekdikti untuk selalu mengejar berbagai ketinggalan pendidikan dengan berbagai cara, mengingat pendidikan idealnya proses sepanjang hayat, maka lulusan atau keluaran dari suatu proses pendidikan tertentu harus dipastikan memiliki kompetensi yang diperlukan untuk melanjutkan pendidikannya secara mandiri sehingga esensi tujuan pendidikan dapat dicapai (Nuh, 2013).

Beberapa waktu yang lalu pemerintah mengeluarkan kebijakan penggantian kurikulum KTSP menjadi kurikulum 2013. Kebijakan kurikulum 2013 dimaksudkan untuk menyempurnakan berbagai kekurangan yang ada pada kurikulum sebelumnya (Machali, 2014). Implementasi kurikulum
2013 sangat menonjolkan pendekatan saintifik dengan pembelajaran yang berpusat pada peserta didik (Machin, 2014). Kurikulum 2013 berfokus pada penerapan pembelajaran yang aktif, kreatif dan mandiri melalui pendekatan saintifik. Implementasi kurikulum 2013 membutuhkan perubahan paradigma pembelajaran dari pembelajaran konvensional yang hanya dilakukan di kelas, menjadi pembelajaran yang mengaktifkan siswa untuk menggunakan aneka sumber belajar yang dapat diperoleh di luar kelas (Sani, 2014).

Perubahan kebijakan terjadi dalam kurun waktu satu setengah tahun pelaksanaan Kurikulum 2013. Pertengahan tahun ajaran 2014/2015 pemerintah secara resmi mengeluarkan kebijakan baru terkait dengan pelaksanaan Kurikulum 2013 di seluruh sekolah di Indonesia. Permendikbud Nomor 160 Tahun 2014 pasal 1 tentang Pemberlakuan Kurikulum Tahun 2006 dan Kurikulum 2013 menjelaskan bahwa pemberhentian pelaksanaan Kurikulum 2013 pada sekolah di luar sekolah rintisan Kurikulum 2013 dan pemberlakuan kembali Kurikulum 2006 pada sekolah tersebut sampai ada ketetapan baru bagi sekolah di luar sekolah rintisan Kurikulum 2013 untuk kembali melaksanakan Kurikulum 2013. Permendikbud Nomor 160 Tahun 2014 pasal 2 juga menjelaskan tata pelaksanaan Kurikulum 2013 bagi sekolah rintisan Kurikulum 2013 yang menjelaskan bahwa satuan pendidikan (sekolah rintisan Kurikulum 2013) yang telah melaksanakan Kurikulum 2013 selama tiga semester tetap menggunakan Kurikulum 2013. Sekolah rintisan Kurikulum 2013 dapat berganti kembali melaksanakan Kurikulum 2006 dengan melakukan pelaporan pada dinas berwenang, terkait dengan pertimbangan untuk kembali kepada Kurikulum tahun 2006.

Saifurahman dan Tri Ujiati (2013: 60) menyatakan bahwa, "Pembelajaran bukan 
hanya sekedar menekankan kepada pengertian konsep-konsep belaka, tetapi bagaimana melaksanakan proses pembelajarannya, dan meningkatkan kualitas proses pembelajaran tersebut, sehingga pembelajaran tersebut menjadi benar-benar bermakna". Permendikbud No. 103 Tahun 2014 pembelajaran merupakan suatu proses pengembangan potensi dan pembangunan karakter setiap peserta didik sebagai hasil dari sinergi antara pendidikan yang berlangsung di sekolah, keluarga, dan masyarakat. Permendikbud Nomor 103 Tahun 2014 telah mengatur tentang mekanisme pelaksanaan pembelajaran, meliputi: (1) perencanaan, (2) pelaksanaan, dan (3) daya dukung. Pada tahap perencanaan pembelajaran diwujudkan dengan penyusunan rencana pelaksanaan pembelajaran (RPP). Hasil observasi awal melalui wawancara dan observasi di SMKN 9 Semarang dan SMK Palebon Semarang menunjukkan masih terdapat hambatan khususnya dalam menerapkan tuntutan dalam kurkulum 2013 ke proses pembelajaran. Penelitian ini dimaksudkan untuk mengetahui implementasi kurikulum 2013.

\section{METODE PENELITIAN}

\section{Key informant interviews}

Kami melakukan wawancara dengan informan kunci yaitu dari guru mata pelajaran, karena beliau merupakan informan yang paling mengetahui proses kegiatan belajar mengajar di kelas, wakil kepala sekolah bidang kurikulum, serta para siswa.

\section{Semi-Structured interviews}

Terdapat 16 siswa yang kami ambil secara acak untuk dijadikan informan. Wawancara dengan mahasiswa terkait proses pembela-jaran selama di kelas.

3. Desk Review

Artikel ini fokus pada penerapan kurikulum 2013 dalam proses belajar mengajar di dalam kelas. Desk review dilakukan melalui review beberapa laporan prestasi akademik, dokumen perangkat pembelajaran dan dokumentasi kegiatan berupa foto-foto.

4. Observasi

Pengamatan dilakukan dengan cara mengidentifikasi seberapa jauh keaktifan dan partisipasi mahasiswa dalam proses pembelajaran.

5. Analysis and validity

Tiga komponen analisis yaitu reduksi data, penyajian data dan penarikan kesimpulan (verifikasi) (Miles and Huberman). Aktivitasnya dilakukan dengan bentuk interaktif dengan proses mengalir (siklus), analisis dilaksanakan secara bersamaan (serentak) dengan proses pengumpulan data. Hal ini berarti bahwa analisis tidak dilakukan setelah data yang dikumpulkan secara keseluruhan telah terkumpul.

\section{HASIL DAN PEMBAHASAN}

Penelitian ini mengambil beberapa lokasi penelitian di Sekolah Menengah Kejuruan yang ada di Semarang, di antaranya SMKN 9 Semarang dan SMK Palebon. Ketiga sekolah ini merupakan sekolah piloting yang ditunjuk oleh pemerintah daerah setempat untuk mengimplementasikan Kurikulum 2013. Hasil dokumentasi RPP yang telah dibuat oleh guru kearsipan baik di SMK Negeri 9 Semarang, SMK Palebon dan SMK Negeri 2 Semarang ditemukan bahwa RPP tersebut memuat hal-hal, yaitu: (1) identitas pendidikan dan pelajaran yang terdiri dari satuan pendidikan, kelas/semester, mata pelajaran, materi pokok, jadwal pertemuan, alokasi waktu, (2) kompetensi inti, (3) kompetensi dasar, (4) indikator pencapaian kompetensi, (5) tujuan pembelajaran, (6) materi ajar, (7) pendekatan, model dan metode pembelajaran, (8) langkahlangkah pembelajaran, (9) alat dan sumber belajar, dan (10) penilaian hasil belajar. Pada RPP juga dilampirkan dengan soal-soal sebagai tugas bagi siswa, kunci jawaban, indikator penilaian, materi pelajaran dan 
tugas mandiri terstruktur. Temuan di lapangan mengungkapkan bahwa guru kearsipan di SMK Negeri 9 Semarang dan SMK Palebon telah melakukan perencanaan pembelajaran kearsipan dengan cara membuat perangkat pembelajaran mata diklat Kearsipan berupa rencana pelaksanaan pembelajaran (RPP) yang disusun berdasarkan silabus, kalender pendidikan, buku teks pelajaran, perhitungan minggu efektif, dan program semester.

Tabel 1. Kesesuaian Pelaksanaan Pembelajaran di SMK Negeri 9 dengan Mekanisme Pelaksanaan Pembelajaran Kurikulum 2013

\begin{tabular}{|c|c|c|c|c|}
\hline Mekanisme & Kegiatan & $\begin{array}{c}\text { Pelaksanaan di kelas } \\
\text { X SMK N } 9 \\
\text { Semarang }\end{array}$ & Kuikulum 2013 & Keterangan \\
\hline $\begin{array}{l}\text { Perencanaan } \\
\text { Pembelajaran }\end{array}$ & $\begin{array}{l}\text { Penyusunan } \\
\text { RPP }\end{array}$ & $\begin{array}{l}\text { 1) Identitas dan } \\
\text { pendidikan yang } \\
\text { pelajaran satuan } \\
\text { terdiri dari pendidikan, } \\
\text { pentajaran, } \\
\text { kelas/semester, } \\
\text { mata pokok, } \\
\text { materi jadwal pelan } \\
\text { jadtemuan, } \\
\text { alokasi waktu; } \\
\text { 2) Kompetensi inti; } \\
\text { 3) Kompetensi } \\
\text { dasar; } \\
\text { 4) Indikator } \\
\text { pencapaian } \\
\text { kompetensi; } \\
\text { 5) Tujuan } \\
\text { pembelajaran; } \\
\text { 6) Materi ajar; } \\
\text { 7) Metode } \\
\text { pembelajaran; } \\
\text { 8) Langkah-langkah } \\
\text { pembelajaran } \\
\text { (kegiatan } \\
\text { pembelajaran); }\end{array}$ & 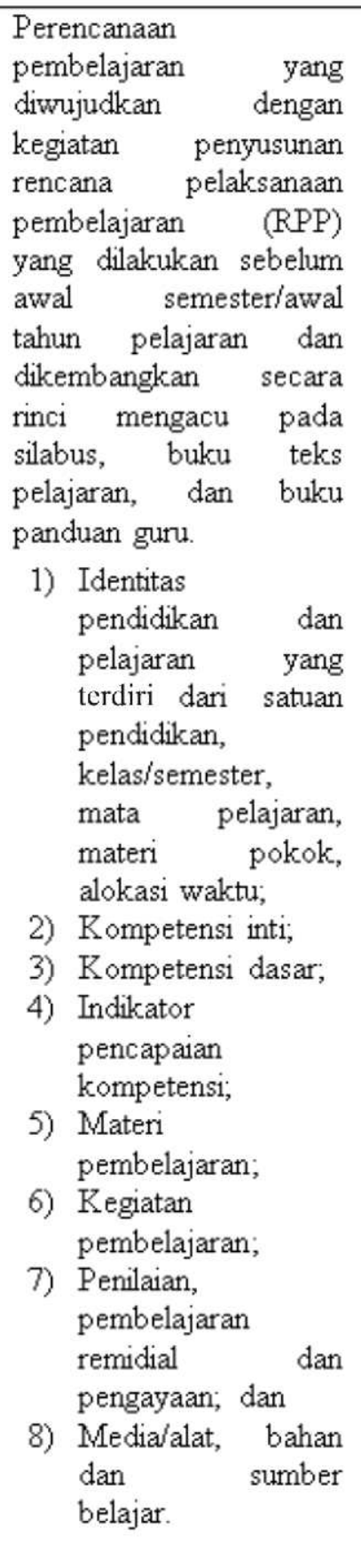 & Sesuai \\
\hline
\end{tabular}


Pelaksanaan Kegiatan Pembelajaran Pendahuluan
9) Alat dan sumber belajar, dan

10) Penilaian hasil belajar.

1) Gunu mengawali pembelajaran tepat waktu, hanya saja menjelang akhir semester terdapat kesibukan di luar jam mengajar sehingga terkadang guru terlambat hingga tidak masuk ke dalam kelas. Dengan respon dari peserta didik yang tertib dan duduk di kursi masingmasing ketika guru memasuki kelas;

2) Guru memberikan salam/doa, memeriksa

kehadiran peserta didik serta

memeriksa

1relas.

kebersihan kelas. Dengan respon dari peserta didik yang menjawab salam dan turut menjaga kebersihan kelas;

3) Guru mereview materi

pembelajaran pada pertemuan

sebelumnya, dengan cara mengulas kembali materi secara garis besar dan membuat pertanyaan untuk peserta didik;

4) Guru menyampaikan kompetensi yang akan dicapai serta manfaatnya dalam kehidupan seharihari; dan
1) Mengucapkan salam/doa;

2) Memeriksa kehadiran didik;

3) Menjelaskan tujuan/kompetensi yang ingin dicapai serta manfaatnya bagi kehidupan;

4) Mereview materi pembelajaran yang sudah dipelajari dan dikembangkan sebelumnya mengkaitkannya dengan kompetensi yang akan dipelajari dan dikembangkan;

5) Menyampaikan garis besar cakupan materi dan kegiatan yang akan dilakukan;

6) Menyampaikan lingkup dan teknik penilaian yang akan digunakan; dan

7) Mengkondisikan suasana kelas yang menyenangkan.
Kurang sesuai (Guru belum melakukan

penyampaian lingkup dan teknik penilaian yang akan digunakan; guru juga belum bisa sepenuhnya mengkondisikan kelas dengan suasana belajar yang dan menyenangkan). 
5) Guru

menyampaikan

garis besar cakupan

materi dan kegiatan

yang akan

dilakukan. Dengan

respon dari peserta

didik yang

memiliki informasi

awal terkait dengan

topik pelajaran

meskipun hanya

sedikit dan tidak

semua peserta

memiliki.

Kegiatan Inti Kegiatan

Pembelajaran

1) Guru memfasilitasi peserta didik untuk mengamati

Dalam pembelajaran Sesuai

langsung peserta didik

melakukan kegiatan

mengamati, menanya,

mengumpulkan

2) Memancing

peserta

informasi/mencoba,

bertanya

didik

menalar/mengasosiasi,

dan

3) Memfasilitasi

peserta

didik

mengomunikasikan.

mengumpulkan

informasi

4) Memfasilitasi

peserta didik untuk menalar/asosiasi

5) Memfasilitasi

peserta didik untuk mengkomunikasi

Metode

Pembelajaran

Menggunakan lebih

dari satu jenis metode

yaitu ceramah, tanya

Setiap

pembelajaran dapat

digunakan berbagai

metode dan teknik

pembelajaran.

jawab, praktik dan

penugasan.

Pengguaan media pembelajaran

Menggunakan

dari satu jenis media pembelajaran

(LCD

proyektor, hard copy

dan powerpoin)
Media pembelajaran, Sesuai berupa alat bantu proses

pembelajaran untuk

menyampaikan materi

pelajaran; 


\begin{tabular}{|c|c|c|c|}
\hline & $\begin{array}{l}\text { Kegiatan } \\
\text { pembelajaran yang } \\
\text { inspiratif, dan } \\
\text { menyenangkan serta } \\
\text { cukup memotivasi } \\
\text { peserta didik untuk } \\
\text { berpartisipasi. }\end{array}$ & $\begin{array}{lr}\text { Proses pembelajaran } \\
\text { diselenggarakan secara } \\
\text { interaktif, } \\
\text { menyenangkan, } \\
\text { menantang, inspiratif, } \\
\text { memotivasi peserta } \\
\text { didik rutuk } \\
\text { berpartisipasi aktif, } \\
\text { serta memberikan ruang } \\
\text { yang cukup bagi } \\
\text { prakarsa, kreativitas, } \\
\text { dan kemandirian sesuai } \\
\text { dengan bakat, minat, } \\
\text { kemampuan, r dan } \\
\text { perkembangan fisik } \\
\text { serta psikologis peserta } \\
\text { didik. }\end{array}$ & $\begin{array}{l}\text { Kurang Sesuai } \\
\text { (Kegiatan } \\
\text { pembelajaran } \\
\text { kurang } \\
\text { menantang dan } \\
\text { interaktif. Di sini } \\
\text { siswa masih } \\
\text { cenderung pasif } \\
\text { dan guru yang } \\
\text { lebih aktif) }\end{array}$ \\
\hline & 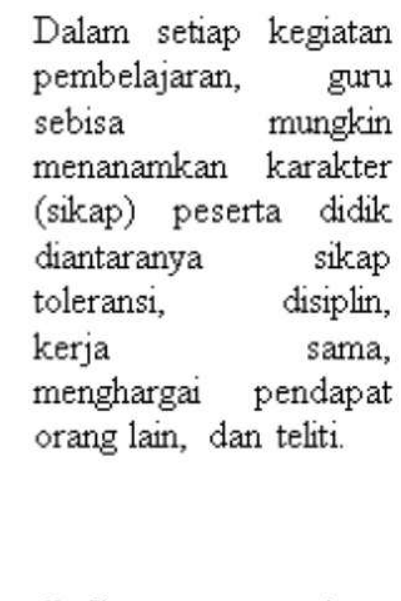 & $\begin{array}{l}\text { Menekankan } \\
\text { perkembangan sikap } \\
\text { peserta didik pada } \\
\text { kompetensi dasar dari } \\
\text { KI-1 dan KI-2 } \\
\text { diantaranya mensyukuri } \\
\text { karunia Tuhan, jujur, } \\
\text { teliti, kerja sama, } \\
\text { toleransi, disiplin, taat } \\
\text { aturan, menghargai } \\
\text { pendapat orang lain } \\
\text { yang tercantum dalam } \\
\text { silabus dan RPP. }\end{array}$ & Sesuai \\
\hline $\begin{array}{l}\text { Kegiatan } \\
\text { Penutup }\end{array}$ & $\begin{array}{l}\text { 1) Guru membuat } \\
\text { kesimpulan } \\
\text { pelajaran. Dengan } \\
\text { respon dari peserta } \\
\text { didik yang ikut } \\
\text { membuat } \\
\text { kesimpulan. }\end{array}$ & $\begin{array}{l}\text { 1) Membuat } \\
\text { rangkuman/simpulan } \\
\text { pembelajaran; } \\
\text { 2) Melakukan refleksi } \\
\begin{array}{lr}\text { terhadap kegiatan } \\
\text { yang rudah } \\
\text { dilaksanakan; }\end{array}\end{array}$ & $\begin{array}{l}\text { Kurang sesuai } \\
\text { (Guru tidak } \\
\text { merencanakan } \\
\text { hal-hal seperti } \\
\text { pengayaan, } \\
\text { layanan } \\
\text { konseling dan }\end{array}$ \\
\hline & $\begin{array}{lr}\text { 2) Guru melakukan } \\
\text { refleksi terhadap } \\
\text { kegiatan yang } \\
\text { sudah dilakukan; } \\
\text { 3) Guru memberikan } \\
\text { umpan } \quad \text { balik } \\
\text { dengan } \quad \text { cara } \\
\text { memberikan } \\
\text { pertanyaan, } \\
\text { pernyataan, dan } \\
\text { pengulangan } \\
\text { dari materi; } \\
\text { 4) Guruti } \\
\text { merencanakan } \\
\text { kegiatan tindak }\end{array}$ & $\begin{array}{l}\text { 3) Memberikan umpan } \\
\text { balik terhadap proses } \\
\text { dan hasil } \\
\text { pembelajaran; } \\
\text { 4) Melakukan } \\
\text { penilaian; } \\
\text { 5) Merencanakan } \\
\text { kegiatan tindak lanjut } \\
\text { dalam bentuk } \\
\text { pembelajaran remidi, } \\
\text { program pengayaan, } \\
\text { layanan konseling } \\
\text { dan/atau memberikan } \\
\text { tugas baik tugas } \\
\text { individual maupun }\end{array}$ & $\begin{array}{l}\text { tidak melakukan } \\
\text { penilaian). }\end{array}$ \\
\hline
\end{tabular}




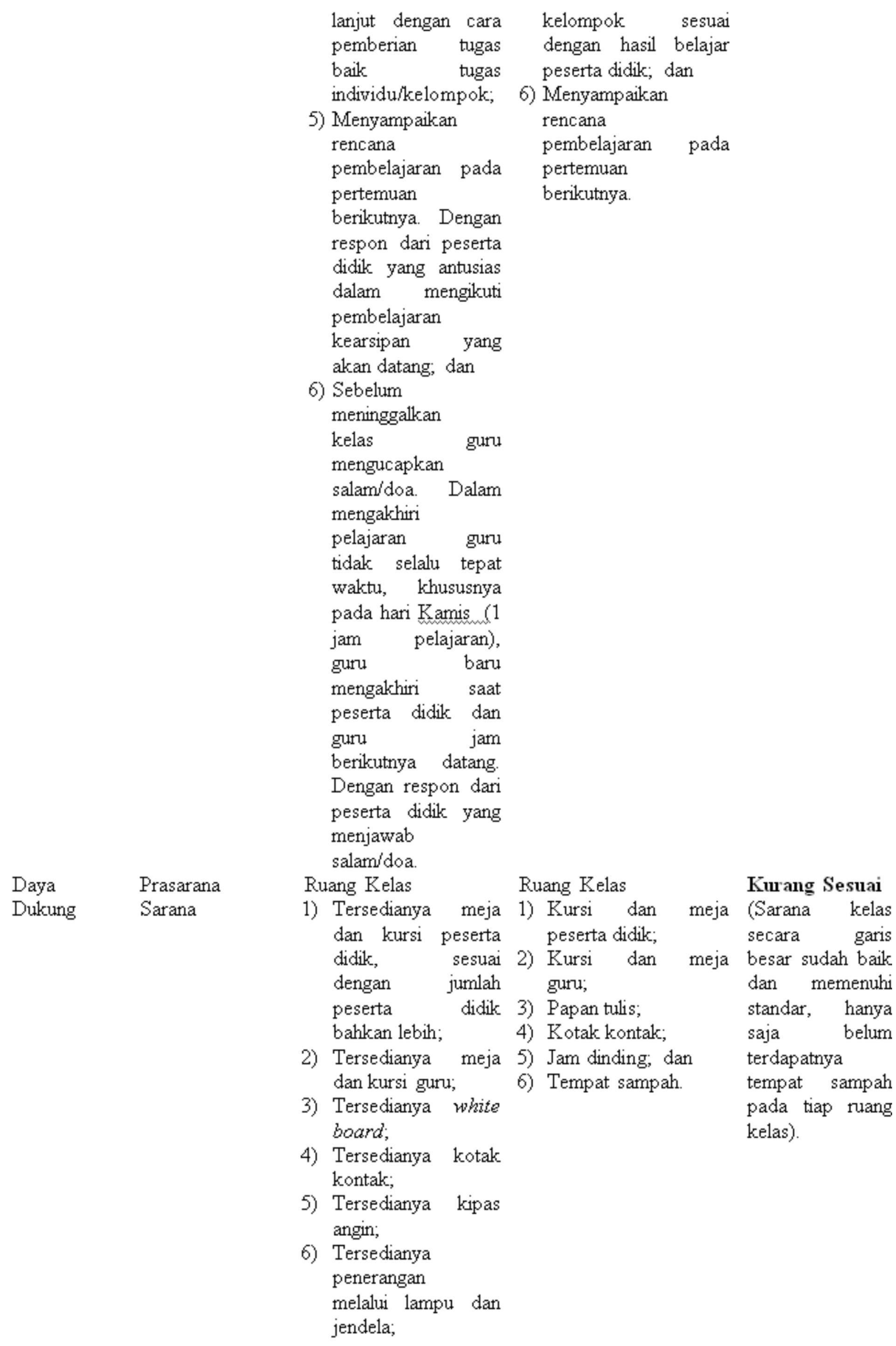



7) Tersedianya jam dinding; dan
8) Tersedianya LCD proyektor.

\begin{tabular}{|c|c|}
\hline $\begin{array}{l}\text { Belum } \\
\text { laboratoriut }\end{array}$ & $\begin{array}{r}\text { terdapat } \\
\text { khusus }\end{array}$ \\
\hline kearsipan. & Praktek \\
\hline cearsipan & nasih \\
\hline dilakukan & kelas \\
\hline ataupun & laboratorium \\
\hline urusan & Adm. \\
\hline $\begin{array}{l}\text { Perkantora } \\
\text { geralatan }\end{array}$ & $\begin{array}{r}\text { dan } \\
\text { kearsipan }\end{array}$ \\
\hline uga me & $\begin{array}{l}\text { disimpan } \\
\text { boratorium }\end{array}$ \\
\hline $\begin{array}{l}\text { san } \\
\text { cant }\end{array}$ & \\
\hline
\end{tabular}

\section{Perpustakaan}

1) Buku teks pelajaran mata diklat kearsipan Kurikulum 2013 belum tersedia, hanya terdapat buku Kearsipan dengan Kurikulum 2006 (KTSP);

2) Sudah terdapat buku pengayaan, baik fiksi maupun nonfiksi;

3) Sudah terdapat buku referensi, berupa Kamus besar Bahasa Indonesia, Karmus

Bahasa Inggris, buku undangundang dan peraturan, dan kitab suci;

1) Sudah terdapat sumber belajar lain, berupa majalah, surat kabar/Koran, dan peta dunia;

2) Tersedianya rak koleksi bacaan

\begin{tabular}{|c|c|c|}
\hline Labor & atorium & Kurang Sesuai \\
\hline Kearsi & pan & (Belum \\
\hline 1) & Meja kerja; & terdapatnya \\
\hline 2) & Kursi & laboratorium \\
\hline & kerja/stool; & khusus \\
\hline 3) & $\begin{array}{l}\text { Lemari simpan } \\
\text { alat dan bahan; }\end{array}$ & kearsipan). \\
\hline 4) & $\begin{array}{ll}\text { Peralatan untuk } \\
\text { pekerjaan } \\
\text { kearsinan. }\end{array}$ & \\
\hline 5) & Papantulis; & \\
\hline 6) & $\begin{array}{l}\text { Kotak kontak; } \\
\text { dan }\end{array}$ & \\
\hline 7) & Tempat sampah. & \\
\hline
\end{tabular}

Perpustakaan Kurang Sesuai

1) Buku teks Masih terdapat pelajaran; beberapa sarana

2) Buku panduan yang jumlahnya pendidik; belum sesuai

3) Buku dengan pengayaan; kebutuhan,

4) Buku referensi; belum terdapat

5) Sumber belajar lain;

6) Rak buku

7) Rak majalah;

8) Rak surat kabar; buku teks

9) Meja baca dan pelajaran mata kursi baca; diklat Kearsipan

10) Kursi kerja dan dengan meja kerja; Kurikulum

11) Lemari katalog; 2013, serta

12) Lemari; belum

13) Lemarirak terdapatnya simpan tas; buku panduan

14) Papan pendidik, lemari pengumuman; dan lemari/rak

15) Meja simpan tas). multimedia; 


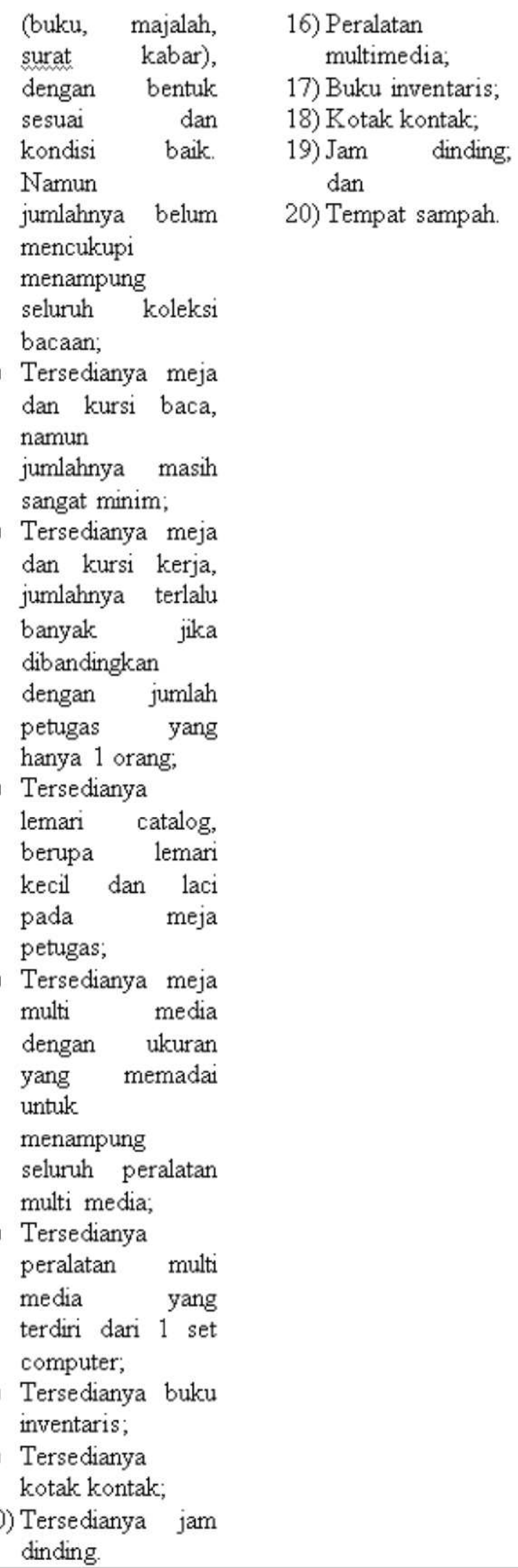

(Sumber: Dokumen rencana pelaksanaan pembelajaran (RPP) mata diklat Kearsipan kelas X SMK Negeri 9 Semarang, Permendikbud No. 103 Tahun 2014 tentang Pembelajaran Pada Pendidikan Dasar Dan Pendidikan Menengah; dan Permendiknas No. 40 Tahun 2008 tentang Standar Sarana Prasarana Sekolah Menengah Kejuruan/Madrasah Aliyah Kejuruan). 
Tabel 2. Kesesuaian Pelaksanaan Pembelajaran di SMK Palebon Semarang dengan Mekanisme Pelaksanaan Pembelajaran Kurikulum 2013

\begin{tabular}{|c|c|c|c|c|}
\hline Mekanisme & Kegiatan & $\begin{array}{c}\text { Pelaksanaan di kelas } \mathrm{X} \\
\text { SMK Palebon } \\
\text { Semarang } \\
\end{array}$ & Kurikulum 2013 & Keterangan \\
\hline \multirow[t]{2}{*}{$\begin{array}{l}\text { Perencanaan } \\
\text { Pembelajaran }\end{array}$} & $\begin{array}{l}\text { Penyusunan } \\
\text { RPP }\end{array}$ & $\begin{array}{l}\text { Guru kearsipan telah } \\
\text { menyusun rencana } \\
\text { pelaksanaan } \\
\text { pembelajaran (RPP) pada } \\
\text { awal tahun ajaran, } \\
\text { mengacu pada silabus, } \\
\text { kaldik dan buku teks } \\
\text { pelajaran, perhitungan } \\
\text { minggu efektif dan } \\
\text { promes yang telah dibuat. }\end{array}$ & $\begin{array}{l}\text { Perencanaan } \\
\text { pembelajaran yang } \\
\text { diwujudkan dengan } \\
\text { kegiatan penyusunan } \\
\text { rencana pelaksanaan } \\
\text { pembelajaran (RPP) } \\
\text { yang dilakukan } \\
\text { sebelum awal } \\
\text { semester/awal tahun } \\
\text { pelajaran dan } \\
\text { dikembangkan } \\
\text { secara rinci mengacu } \\
\text { pada silabus, buku } \\
\text { teks pelajaran, dan } \\
\text { buku panduan guru. }\end{array}$ & Sesuai \\
\hline & Format RPP & $\begin{array}{l}\text { 1) Identitas pendidikan } \\
\text { dan pelajaran yang } \\
\text { terdiri dari satuan } \\
\text { pendidikan, } \\
\text { kelas/semester, mata } \\
\text { pelajaran, materi } \\
\text { pokok, jadwal } \\
\text { pertemuan, alokasi } \\
\text { waktu; } \\
\text { 2) Kompetensi inti; } \\
\text { 3) Kompetensi dasar; } \\
\text { 4) Indikator pencapaian } \\
\text { kompetensi; } \\
\text { 5) Tujuan } \\
\text { pembelajaran; } \\
\text { 6) Materi ajar; } \\
\text { 7) Metode } \\
\text { pembelajaran; } \\
\text { 8) Langkah-langkah } \\
\text { pembelajaran } \\
\text { (kegiatan } \\
\text { pembelajaran); } \\
\text { 9) Alat dan sumber } \\
\text { belajar; dan } \\
\text { 10) Penilaian } \\
\text { belajar. hasil }\end{array}$ & $\begin{array}{l}\text { 1) Identitas } \\
\text { pendidikan dan } \\
\text { pelajaran yang } \\
\text { terdiri dari } \\
\text { satuan } \\
\text { pendidikan, } \\
\text { kelas/semester, } \\
\text { mata pelajaran, } \\
\text { materi pokok, } \\
\text { alokasi waktu; } \\
\text { 2) Kompetensi } \\
\text { inti; } \\
\text { 3) Kompetensi } \\
\text { dasar; } \\
\text { 4) Indikator } \\
\text { pencapaian } \\
\text { kompetensi; } \\
\text { 5) Materi } \\
\text { pembelajaran; } \\
\text { 6) Kegiatan } \\
\text { pembelajaran; } \\
\text { 7) Penilaian, } \\
\text { pembelajaran } \\
\text { remidial dan } \\
\text { pengayaan; dan } \\
\text { 8) Media/alat, } \\
\text { bahan an dan } \\
\text { sumber belajar. }\end{array}$ & Sesuai \\
\hline
\end{tabular}




\begin{tabular}{|c|c|c|c|c|c|}
\hline Pelaksanaan & $\begin{array}{l}\text { Kegiatan } \\
\text { Pendahuluan }\end{array}$ & 4) & 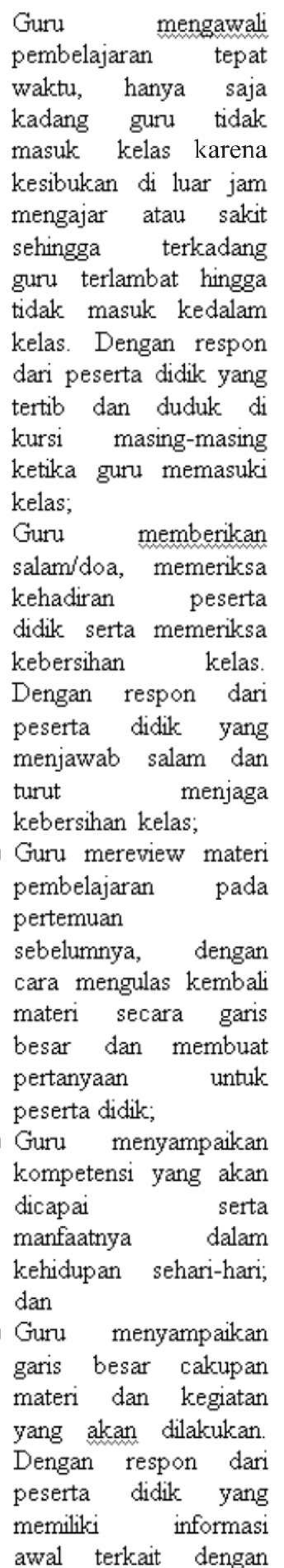 & 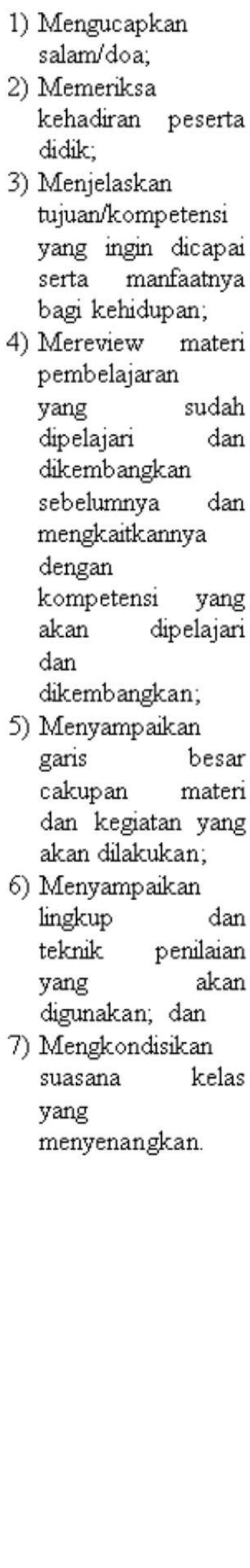 & $\begin{array}{l}\text { Kurang } \\
\text { sesuai } \\
\text { (Guru } \\
\text { belum } \\
\text { melakukan } \\
\text { penyampai } \\
\text { an lingkup } \\
\text { dan teknik } \\
\text { penilaian } \\
\text { yang akan } \\
\text { diguna- } \\
\text { kan; guru } \\
\text { juga } \\
\text { belum bisa } \\
\text { sepenuh- } \\
\text { nya } \\
\text { mengkon- } \\
\text { disikan } \\
\text { kelas } \\
\text { dengan } \\
\text { suasana } \\
\text { belajar } \\
\text { yang } \\
\text { menye- } \\
\text { nangkan). }\end{array}$ \\
\hline
\end{tabular}




$\begin{array}{lr}\text { topik } & \text { pelajaran } \\ \text { meskipun } & \text { hanya } \\ \text { sedikit dan } & \text { tidak } \\ \text { semua } & \text { peserta } \\ \text { memiliki. } & \end{array}$

Kegiatan

Kegiatan Pembelajaran

Inti
Dalam pembelajaran langsung peserta didik melakukan kegiatan mengamati, menanya, mengumpulkan informasi/mencoba, menalar/mengasosiasi, dan mengomunikasikan.
Sesuai peserta didik untuk mengamati

2) Memancing peserta didik bertanya

3) Memfasilitasi peserta didik mengumpulkan informasi

4) Memfasilitasi peserta didik untuk menalar/asosiasi

5) Memfasilitasi peserta didik untuk mengkomunikasi

\section{Metode Pembelajaran}

Menggunakan lebih dari satu jenis metode yaitu ceramah, tanya jawab, praktik dan penugasan.

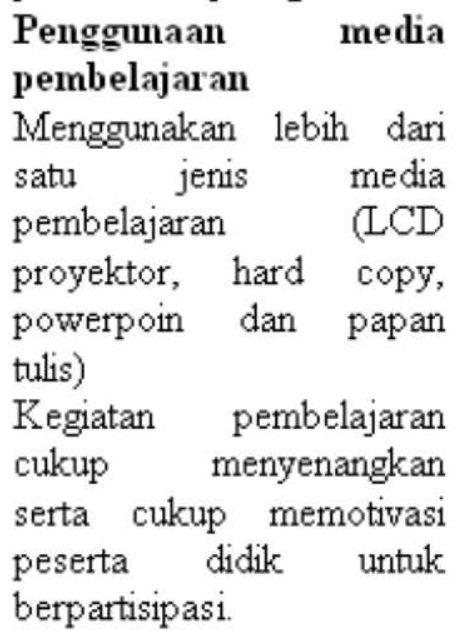
berpartisipasi.
Setiap langkah
pembelajaran dapat digunakan berbagai metode dan teknik pembelajaran

Media pembelajaran, Sesuai berupa alat bantu proses pembelajaran untuk menyampaikan materi pelajaran;

Proses pembelajaran diselenggarakan

secara interaktif, menyenangkan, menantang, inspiratif, memotivasi peserta inspiratif, didik untuk menanberpartisipasi aktif, tang, serta memberikan Interaktif. ruang yang cukup Disini bagi prakarsa, siswa kreativitas, dan masih kemandirian sesuai cenderung dengan bakat, minat, pasif dan kemampuan, dan guru yang 
Kegiatan

Penutup
1) Guru membuat kesimpulan pelajaran. Dengan respon dari peserta didik yang ikut membuat kesimpulan.

2) Guru melakukan refleksi terhadap kegiatan yang sudah dilakukan;

3) Guru memberikan umpan balik dengan cara memberikan pertanyaan, pernyataan, dan pengulangan inti dari materi;

4) Guru merencanakan kegiatan tindak lanjut dengan cara pemberian tugas baik tugas individu/kelompok;

5) Guru menyampaikan rencana pembelajaran pada pertemuan berikutnya. Dengan respon dari peserta didik yang antusias dalam mengikuti pembelajaran perkembangan fisik lebih aktif) serta psikologis peserta didik.

Menekankan

Sesuai perkembangan sikap peserta didik pada kompetensi dasar dari KI-1 dan KI-2 diantaranya mensyukuri karunia Tuhan, jujur, teliti, kerja sama, toleransi, disiplin, taat aturan, menghargai pendapat orang lain yang tercantum dalam silabus dan RPP.

1) Membuat Kurang rangkuman/simpul sesuai an pembelajaran; (Guru

2) Melakukan tidak refleksi terhadap merencana kegiatan yang kan halsudah hal seperti dilaksanakan; peng-

3) Memberikan ayaan, umpan balik layanan terhadap proses konseling dan hasil pembelajaran;

4) Melakukan penilaian;

5) Merencanakan kegiatan tindak lanjut dalam bentuk pembelajaran remidi, program pengayaan, layanan konseling dan/atau memberikan tugas baik tugas individual maupun kelompok sesuai dengan hasil belajar peserta didik; dan 


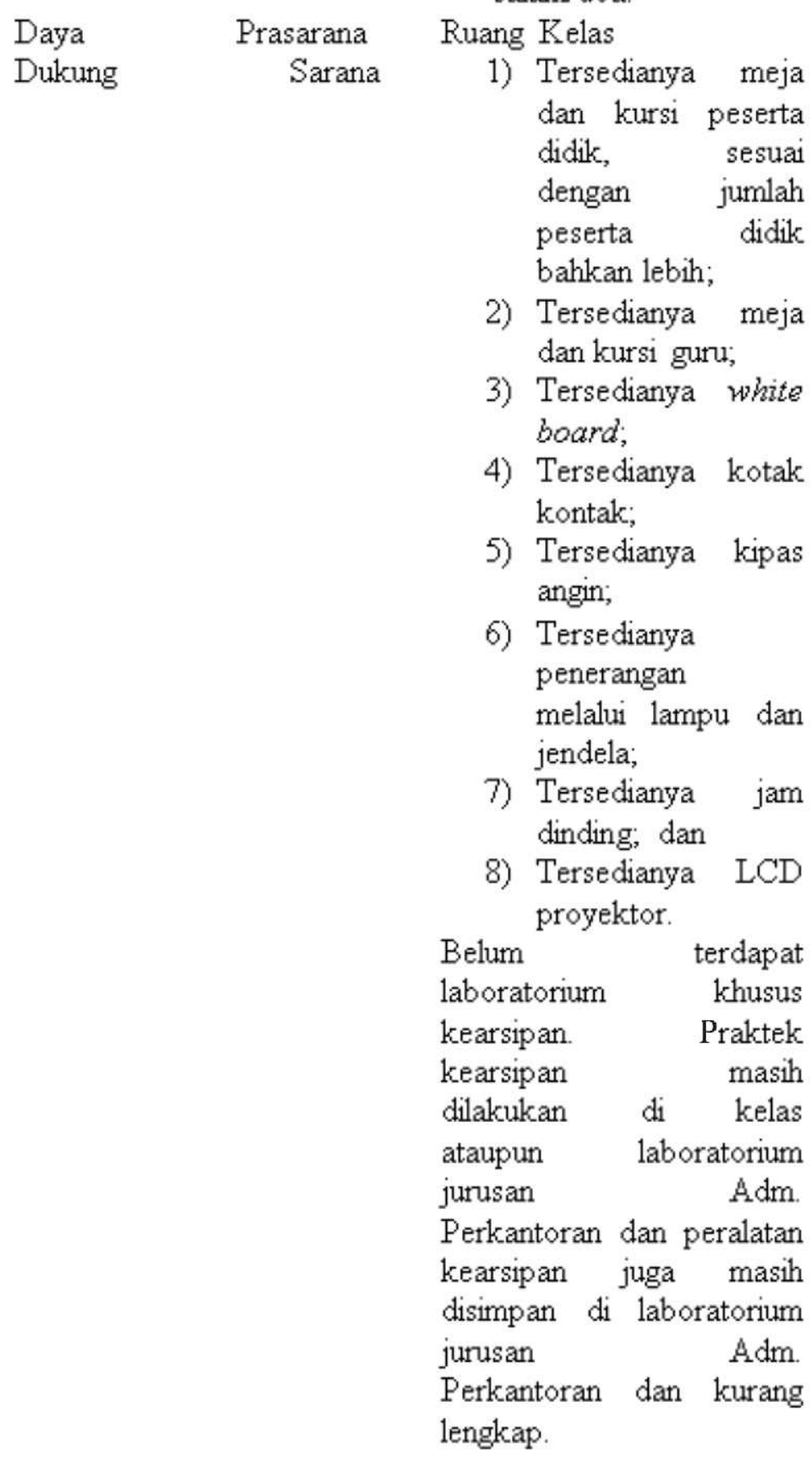

kearsipan yang akan

datang; dan

6) Sebelum

meninggalkan kelas

guru mengucapkan

salam/doa. Dengan

respon dari peserta

didik yang menjawab

salam/doa.

Daya

Prasarana

Sarana

1) Tersedian dan kursi peserta

didik, sesuai

dengan jumlah

peserta didik

bahkan lebih;

Tersedianya meja dan kursi guru;

Tersedianya white

kontak

Tersedianya kipas ngin;

Tersedianya melalui lampu dan jendela;

Tersedianya jam

Tersedianya LCD proyektor

\begin{tabular}{lrr}
$\begin{array}{l}\text { Belum } \\
\text { laboratorium }\end{array}$ & $\begin{array}{r}\text { terdapat } \\
\text { khusus } \\
\text { kearsipan. }\end{array}$ & $\begin{array}{r}\text { Praktek } \\
\text { kearsipan }\end{array}$ \\
$\begin{array}{l}\text { masih } \\
\text { dilakukan }\end{array}$ & di & kelas \\
ataupun & laboratorium \\
jurusan & \multicolumn{2}{c}{ Adm. } \\
Perkantoran dan peralatan \\
kearsipan juga masih \\
disimpan di laboratorium \\
jurusan \\
$\begin{array}{l}\text { Perkantoran } \\
\text { lengkap. }\end{array}$
\end{tabular}

6) Menyampaikan

rencana

pembelajaran

pada pertemuan

berikutnya.

$\begin{aligned} & \text { Ruang Kelas } \text { Kurang } \\ & \text { 1) Kursi dan } \text { Sesuai } \\ & \text { meja peserta } \text { (Sarana } \\ & \text { didik; dan } \text { kelas } \\ & \text { 2) Kursi secara } \\ & \text { meja guru; } \text { garis besar } \\ & \text { 3) Papan tulis; } \text { sudah baik } \\ & \text { 4) Kotak } \text { dan } \\ & \text { kontak; } \text { memenuhi } \\ & \text { 5) Jam dinding; } \text { standar, } \\ & \text { dan } \text { hanya saja } \\ & \text { 6) Tempat } \text { belum } \\ & \text { sampah. } \text { terdapat- } \\ & \text { nya tempat } \\ & \text { sampah } \\ & \text { pada tiap } \\ & \text { ruang } \\ & \text { kelas). }\end{aligned}$

\section{Laboratorium Kurang}

Kearsipan Sesuai

1) Meja kerja; (Belum

2) Kursi terdapatkerja/stool; nya

3) Lemari laboratosimpan alat rum dan bahan; khusus

4) Peralatan kearsipan untuk dan alat pekerjaan praktik kearsipan; yang

5) Papan tulis; kurang

6) Kotak memadai kontak; dan misalkan

7) Tempat seperti sampah. filling 


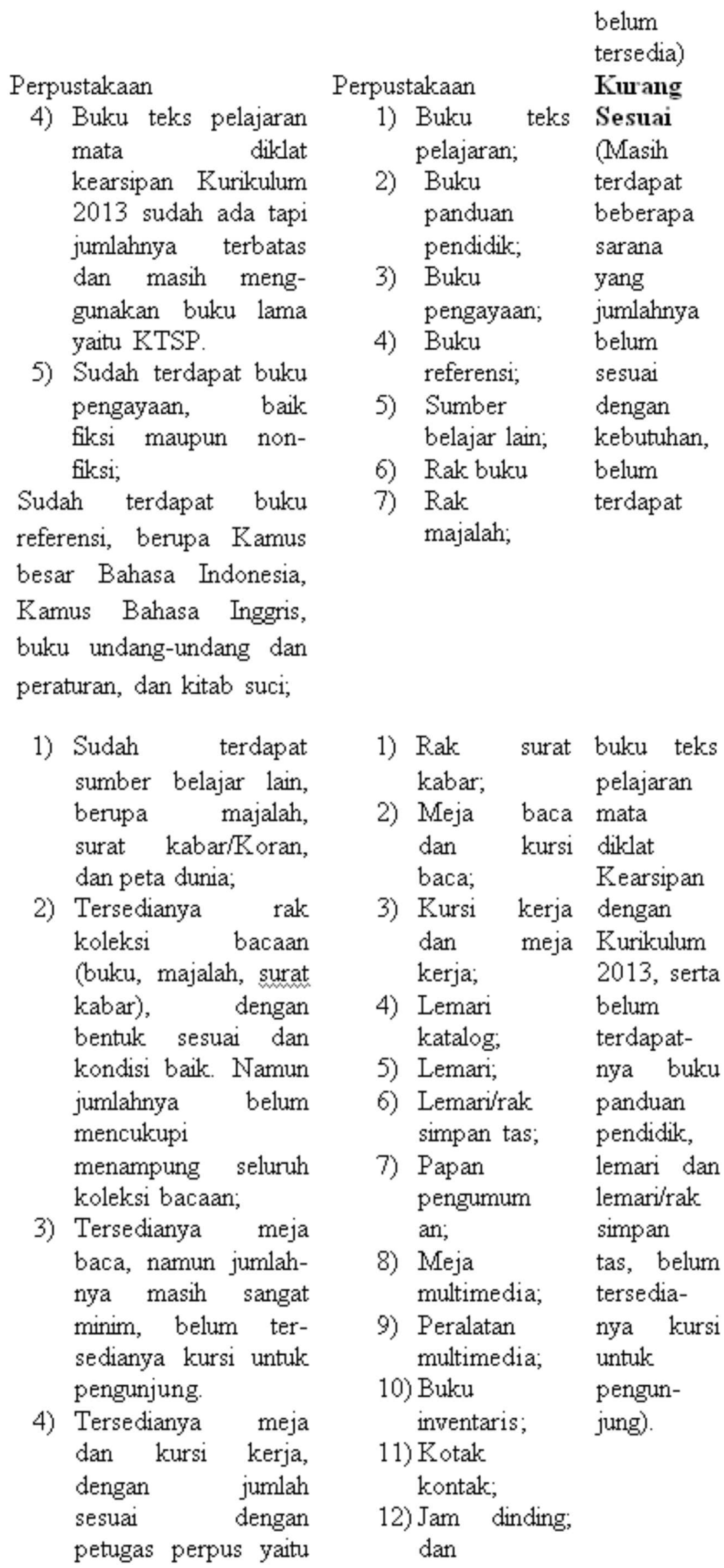




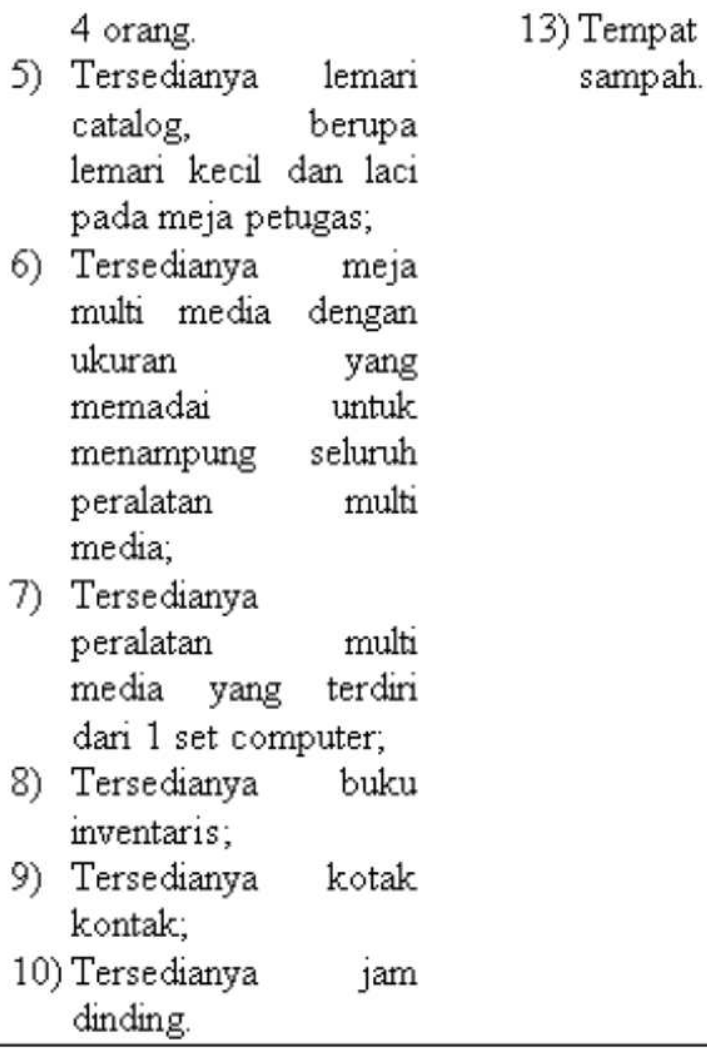

\section{PENUTUP}

\section{Simpulan}

Kegiatan perencanaan pembelajaran, guru telah membuat RPP berdasarkan Silabus yang diberikan, kaldik dan buku teks pelajaran, perhitungan minggu efektif dan promes/porta. Menggunakan pendekatan saintific, namun belum menerapkan modelmodel pembelajaran yang direkomendasikan dalam pendekatan saintifik. Pembelajaran menggunakan ceramah dan presentasi.

\section{Saran}

Sebaiknya guru menggunakan pembelajaran dengan pendekatan saintific sesuai dengan yang di rekomendasikan pemerintah yaitu (Problem Base Learning, Discovery Learning, Project Base Learning, Inquiry Learning).

\section{DAFTAR PUSTAKA}

Ahmad, S. (2014). Problematika Kurikulum 2013 dan Kepemimpinan Instruksional Kepala Sekolah. Jurnal Pencerahan, 8 (2).
Bariyah, L. (2014). ANALISIS K E S E S U A I A N R P P D A N PELAKSANAAN PEMBELAJARAN GURU SMPN DI KABUPATEN MOJOKERTO PADA SUB MATERI F O T O S IN T ES IS DEN G A N KERIKULUM 2013. BioEdu, 3(3).

Hosnan, M. 2014. Pendekatan Saintifik dan Kontekstual dalam Pembelajaran Abad 21. Bogor: Ghalia Indonesia.

Kwartolo, Y. (2002). Catatan kritis tentang kurikulum berbasis kompetensi. Jurnal Pendidikan Penabur, 1 (1), 106-116.

Machali, I. (2014). Kebijakan Perubahan Kurikulum 2013 dalam Menyongsong Indonesia Emas Tahun 2045. Jurnal Pendidikan Islam, 3 (1), 1345.

Machin, A. (2014). Implementasi pendekatan saintifik, penanaman karakter dan konservasi pada pembelajaran materi pertumbuhan. Jurnal Pendidikan IPA Indonesia, 3(1). 
Nuh, M. (2013). Kurikulum 2013. Sumber: http://www. kemdiknas. go. id.

Peraturan Menteri Pendidikan dan Kebudayaan Nomor 103 Tahun 2014 tentang Pembelajaran pada Pendidikan Dasar dan Pendidikan Menengah. 2014. Jakarta: Kementerian Pendidikan dan Kebudayaan.

Peraturan Menteri Pendidikan dan Kebudayaan Nomor 70 Tahun 2013 tentang Kerangka Dasar dan Struktur Kurikulum Sekolah Menengah Kejuruan/Madrasah Aliyah Kejuruan. 2013. Jakarta: Kementerian Pendidikan dan Kebudayaan.

Peraturan Menteri Pendidikan dan Kebudayaan Nomor 81a Tahun 2013 tentang Implementasi Kurikulum.
2013. Jakarta: Kementerian Pendidikan dan Kebudayaan.

Peraturan Menteri Pendidikan Nasional Nomor 40 Tahun 2008 tentang Standar Sarana dan Prasarana Sekolah Menengah Kejuruan/Madrasah Aliyah Kejuruan (SMK/MAK). 2008. Jakarta : Kementerian Pendidikan Nasional.

Sani, R. A. (2014). Pembelajaran saintifik untuk implementasi kurikulum 2013.

Sariono (2013). Kurikulum 2013: "Kurikulum Generasi Emas". E-Jurnal Dinas Pendidikan Kota Surabaya. 3, 1-9.

Syaifurrahman dan Tri Ujiati. 2013. Manajemen Dalam Pembelajaran. Jakarta: PT. Indeks. 